\title{
The Boston Consulting Group's strategic menagerie
}

\author{
C.G. Robinson
}

Graduate School of Business Administration, University of the Witwatersrand, Johannesburg

In this, the first in a series of three articles which summarize the Boston Consulting Group's approach to setting strategy, problems of funding growth and allocating resources around a portfolio of products or strategic business units are highlighted. The relationships between the stage of the product life cycle, the funding requirements of a business, and the alternatives for generating funds are explored. Growth and risk issues are highlighted and the maximum sustainable rate of growth from intemally generated sources is derived. The impact of the experience curve on capital structure, production costs, and competitive position emphasizes the interaction between life cycle position, cost position, profitability, and cash flow. This logically leads to the Boston Consulting Group's Growth Share Matrix as a basis for resource allocation around a portfolio of businesses. Optimum cash flow and investment criteria are arrived at.

S. Afr. J. Bus. Mgmt. 1985, 16: $76-86$

In hierdie artikel, die eerste van drie waarin die Boston Konsultante Groep se benadering tot strategieformulering opgesom word, word die probleme van groeibefondsing, en die toedeling van hulpbronne van 'n portefeulje van produkte of strategiese besigheidseenhede bespreek. Die verbande tussen die stadia van 'n produk se lewensiklusse, die befondsingsbehoeftes van 'n besigheid en die alternatiewe moontlikhede vir die verkryging van fondse word ondersoek. Groei- en risiko-probleme word beklemtoon en die maksimum handhaafbare groeitempo van internverwekte bronne word afgelei. Die impak van die ervaringskurwe op die kapitaalstruktuur, produksiekoste en mededingende posisie beklemtoon die interaksie tussen lewensiklusposisie, koste-posisie, winsgewendheid en kontantvloei. Dit lei logies tot die Boston Konsultante Groep se GroeiAandeel Matriks as 'n basis vir die toedeling van hulpbronne van 'n besigheid se portefeulje. Die optimisering van kontantvloei en beleggingskriteria word hierdeur bepaal. S.-Afr. Tydskr. Bedryfst. 1985, 16: 76-86

\section{C.G. Robinson}

Graduate School of Business Administration, University of the Witwatersrand, P.O. Box 31170, Braamfontein, 2017 Republic of South Africa

\section{The resource allocation problem}

Corporate strategic planning for multiproduct or multibusiness companies is a particularly complex problem. The key issues are related to

- what is the expected return for various individual businesses, and

- how to allocate corporate funds among various investment opportunities.

Techniques for strategic planning in a portfolio of products, or businesses, have been developed by the Boston Consulting Group, General Electric, and Shell. These techniques address the resource allocation, cash flow, and the return on investment problems. The Boston Consulting Group points out that, in its experience, the investment allocation problem is a chronic, often unresolved, problem in most corporations and that the investment allocation method is often a subject of dispute among top management, the financial staff, and operating management (Moose \& Zakon, 1972: 63-70).

The problem in fact exists on two levels, namely

- the determination of whether a given investment opportunity is attractive to a company, and

- the question as to how to manage the corporate portfolio by selecting between the various potential investments.

There is a major difference between the investment decision taken on any given investment opportunity and the decision as to the impact of funding on a total portfolio. Some companies handle the problem by breaking down the organization into profit centres of manageable complexity and then treating each as a separate planning unit. Strategies for the units are set separately, then assembled into a corporate-wide plan and adjusted independently to meet corporate financial and performance targets and constraints. This approach is predicated upon the premises that the corporation should invest in all those opportunities whose returns exceed the cost of funds, really the shareholders' opportunity cost. The problem is resolved by considering different investment opportunities and then calculating some measure of the anticipated return on investment via a discounted cash flow or internal rate of return, and then comparing the calculated value with the cost of capital funds or some previously set corporate hurdle rate. Opportunities that hurdle the financial gate are accepted. Those that do not are rejected.

Problems inherent in the simple analysis of individual businesses appear to be the following:

- The imposition of minimum acceptable rates is subvented by managers and project assessors by the simple expedient of 
massaging the underlying assumptions until the calculations yield values that vault the corporate hurdle (Robinson, C.G., Channon, D.F. \& Badler, G.J. - personal observations). In such businesses it is not uncommon to find that the total corporate return on investment is substantially less than the hurdle rate employed for individual projects. This raises questions as to why the total return on investment should be less than the theoretical sum of the component parts.

- In evaluating the deployment of assets, the rigidity of quantification of the techniques employed can, and do, distort the true picture of the various alternatives open to a firm. Factors exist which do not lend themselves to easy numerical analysis by conventional methods. These would include non-quantifiable issues, shared experience and risk trade-offs. Left to intuition the assumptions are massaged to suit the required conclusions (Zakon, 1971).

- Evaluations are usually done on a project, on a one-off basis, and are seldom updated anually to assess the strategic implications of a product or business in the corporate portfolio. This static perspective seems to imply that, frequently, once part of the portfolio, a product or business tends to stay and has a high level of inertia.

- The difficulty in coming to grips explicitly with risk and return trade-offs tends to displace logical strategic analysis with conventional wisdom (Zakon, 1971).

- The lack of creative financial planning can result in conflicting goals and policies with regard to financial parameters such as growth targets, shareholders' return, and liquidity. The Boston Consulting Group argues that the simple assessment of individual businesses separately is inherently suboptimizing the corporation as a whole and that the only strength from portfolio diversification may be that of financial synergy in the market place. According to Henderson (1970):

'A multidivision company without an overall strategy is not even as good as its parts. It is merely a portfolio of non liquid, non tradeable investments, which has added overhead and constraints. Such closed-end investments properly sell at a discount from the sum of the parts.' Attempts have been made to operationalize the pure portfolio approach of fitting risk and return preferences of corporate management to the risk-return profiles of a portfolio of businesses (Carter \& Kalman, 1972: 8-30). The attempts, in which an extension of stock exchange portfolio theory based on well documented literature by Sharpe (1970) and Levy \& Sarnat (1972) was used have not been particularly fruitful. Simplistically stated the problem is to develop a portfolio of investments which maximizes the return relative to risk or minimizes risk relative to return.

This is essentially an extension of the Modigliani-Miller argument (Modigliani \& Miller, 1958: 261-297). This argument assumes that the shareholders' risk/retum portfolio preference can be attained by a personal mixture of the shares of corporations with varying risk-return patterns and a personal mixture of debt and equity. Similarly corporate risk/return preferences can be optimized by a portfolio of corporate investments. It is a direct extension of the argument that shareholders can undo corporate debt/equity decisions through their personal decisions.

Although appealing, the argument neglects the basic difference between corporate and shareholder decisions. The shareholder can buy and sell, in a presumably efficient market. Individual shareholder decisions do not affect the business concerned. The corporation can however both mix various businesses in the portfolio and, by exercising discretion over the resource allocation process, affect the future performance of businesses in the portfolio. Discretion over the resource allocation process is the fundamental difference.

The prime strength of the corporate portfolio is the ability to fund cash from mature cash-generating businesses to fledgling growth businesses without having to expose the individual growth business to the vagaries of equity and financial markets. The large corporate portfolio can manage a growth business more effectively than the private investor because of the ability to fund growth directly.

The multidivisional, multiproduct, company has the ability to channel its resources into the most productive units, a capability that the undiversified firm or the individual investor does not have. Integrated strategic planning at the corporate level can be used to match the total portfolio potential with its resource generation capabilities and to establish guidelines for the sequence and timing of resource transfers. For example, a diversified conglomerate may decide to slow down the growth of its mining equipment division to throw off cash to fund the expansion of its minicomputer division. Integrated planning at the corporate level may deliberately suboptimize the individual business in order to optimize the performance of the corporation as a whole.

The approach adopted by the Boston Consulting Group is to balance cash use with cash generation in order to maximize the growth per dollar invested, or the long-term returns on total corporate investment. The Boston Consulting Group's approach is unique in that a role is assigned to each product or division and that these roles are then integrated into a portfolio strategy. Product roles are assigned on the basis of cash flow potential and cost position relative to the competition, after taking into account the portfolios of competitors. The growth and cash flow potentials and competitive position of each business determines which businesses represent investment opportunities and which should be used to supply investment funds. Businesses with neither cash flow generation capabilities or growth potential become candidates for elimination from the portfolio.

\section{Growth and financial strategy}

There are complex interrelationships between industry growth, pricing policies, financial strategy, and competitive advantage. The relationships are most dramatically highlighted in the case of a rapidly growing industry.

Using the Product Life Cycle Curve (Robinson, 1982b; Masson, 1974 and Levitt, 1975) as a base it is possible to illustrate the funding dilemma associated with a portfolio of products and businesses at different stages of their life cycles (Figure 1). The three key issues at each stage of the life cycle are

- the number and strengths of competitors,

- the cash flow requirements, and

- the funding ability

of each business.

In Stage 1 there are few competitors but cash flow requirements can be high particularly in capital-intensive industries. Recourse to external funding is often limited owing to the jaundiced view of financial agencies.

Stage 2 attracts more entrants and can have even greater cash needs particularly if the industry growth rate is high and investment in fixed and working capital must be undertaken simply to hold market share. Recourse to external funding is limited particularly as balance sheet structures tend to look very strained and various critical ratios scare off even the riskiest backers. 


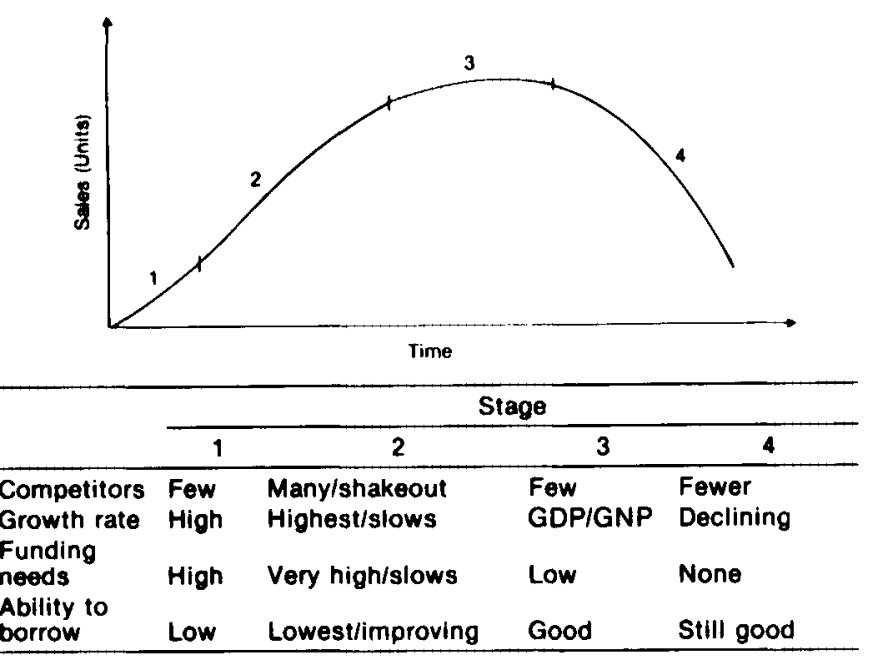

Figure 1 Growth and financial strategy across the product life cycle (Robinson, 1982b).

Stage 3 is characterized by low growth rates and a more stable industry with many of the inadequate competitors having fallen away or been acquired by larger, more dominant firms. Cash requirements drop and access to funds is much improved owing to the track record of the surviving companies and the stability of the industry.

The financial dilemma is that when growth rates are high and cash requirements are great, access to sources of funds are limited, but when growth has slowed and cash requirements are low, or companies are net cash generators, funding becomes relatively easy.

A company's sustainable rate of growth therefore depends on, and is limited by, the rate at which it can generate funds for investment in growth and by the return the company can expect to earm on the funds. It is necessary to determine the interrelationship between debt, risk, dividends, and return on investment before a competent statement of strategy can be made. A company earning $20 \%$ on its assets per annum, and no recourse to external debt, cannot pay out $50 \%$ of its income in dividends and expect to grow at $30 \%$ per annum. It simply cannot generate enough funds to support a high level of growth. In not supporting growth the business may be eroding market share with long-term cost and return implications.

Financial goals and objectives must be developed so as to support the long term strategic goals and objectives. To do so requires an understanding of the interrelationship between the strategic and financial parameters. The Boston Consulting Group provides an approach to do so by concentrating on the cash flow characteristics of businesses (Zakon, 1971).

\section{The determinants of growth}

The determinants of corporate growth are

- the rate of return of the business,

- the use of debt,

- recourse to external equity, and

- the dividend policy pursued.

Dividend payout and capital requirements determine the availability of funds generated by the return on the assets employed. Faced with the funding dilemma, the company should be aware of the implications of the use of each source.

\section{Rate of retum}

The company usually has a characteristic rate of return on assets dependent on the businesses it is in. The rate of return of a business is a function of a number of business and environmental characteristics such as the capital intensity, relative quality, level of vertical integration and the industry concentration (Schoeffler, Buzzell \& Heany, 1974: 137-145 and Roberts, 1981). The Boston Consulting Group, however, claims that, because of the essentially fixed nature of a company's traditional performance, a competently managed firm can normally raise its overall rate of return only by moving into a different business with a higher return (Zakon, 1971: 3). This claim is really both at variance with the PIMS findings (Roberts, 1981) and with the Boston Consulting Group's own claims associated with the experience curve and the effects of dominant market share.

What appears to be implied is that it is difficult to exceed the industry average price and that the firm that uses too high a margin

- invites competitive entry into the market,

- loses market share, and

- dependent on the elasticity of demand, may even forgo turnover and

- grow more slowly than the market average

\section{The use of debt}

The true measure of management's success is the growth in return on shareholders' equity - not simply return on investment. The use of high debt levels allows the firm to lever up a given return on investment into a higher return on equity. Given a constant dividend payout, if a fixed ratio of debt to equity is maintained, a higher sustainable level of growth can be achieved without changing the firm's characteristic rate of return on investment. By balancing the higher return on equity and larger cash flows against the fixed cost of interest payments, a level of debt usage can be set at which growth potential is greatly increased with a lower increase in the overall risk exposure relative to the alternative of finding new businesses.

The use of high levels of debt can enable a firm to:

- Accept lower profit margins and overcome short-term cost disadvantages by speedy movement down the experience curve as a result of capturing a greater share of the markets' growth;

- pay more for assets, especially productive capacity to achieve a technology or scale advantage resulting in better production efficiency; and

- maintain a higher growth rate than the market norm.

The firm is able to accept lower returns on assets than its competitors and still grow at a more rapid rate because a lowreturn business financed with significant amounts of debt can generate high returns on equity and rapid rates of growth. The essence is that the company, by adding financial risk, is reducing the business risk associated with an inability to grow faster than the market norm. A very safe low-return business may offer a higher return on equity, after leveraging, at a lower overall level of risk than an alternative high-risk, high-return business. The use of a strategic approach to debt usage can increase the overall corporate growth rate while lowering the overall risk of the business mix.

\section{Dividend policy}

A trade-off exists between current and future dividends. High initial dividend payouts hold back the sustainable rate of growth while low initial payouts produce more rapid growth and higher future dividends in absolute terms.

All other things being equal, if a firm earns $20 \%$ on equity, an $80 \%$ payout will allow for a growth rate of $4 \%$, while 
a $20 \%$ payout will allow for a growth rate of $16 \%$ per year. It can be shown that by the end of the thirteenth year the lower payout will yield a larger payout in absolute terms.

Growth can only be sustained at high levels of dividend payout if the rate of return on investment is high or if high debt levels can lever up the reduced investments. If increasing margins invites competitive pressure, and if high debt increases risk unacceptably, the situation is difficult. A company paying out a large part of its earnings in dividends and with a high debt ratio cannot grow strongly without

- changing dividend policies, or

- recourse to equity funds.

\section{External equity}

Recourse to external sources of equity is not the easy solution for a number of reasons. The issuing of additional equity has the effect of diluting control and may generate conflicts of interest between established and new equity holders. Secondly the cost incurred in servicing the new equity can be very high when equity financing is substituted for debt leverage with a high dividend payout policy. The higher the target rate of growth, the more difficult it becomes to overcome the dilution incurred. The Boston Consulting Group (Zakon, 1971) uses the relationship

$$
\begin{aligned}
& \text { earnings per share (eps) } \\
& =\text { current eps }\left(\frac{1+\text { earnings growth rate }}{1+\text { share growth rate }}\right)
\end{aligned}
$$

and clearly illustrate the dilution effect for the two cases:

- Firstly, where current eps is $\$ 2,00$ and the earnings growth rate is $20 \%$.

The forecast earnings per share is

$$
2,00\left(\frac{1+, 20}{1,00}\right)=\$ 2,40
$$

Secondly, where all earnings are paid out in dividends and new shares increase the equity by $20 \%$ at a price earnings multiple of $5: 1$.

eps $=\$ 2,00\left(\frac{1+, 20}{1+, 05}\right)=\$ 2,28$

The effect of the additional equity injection is to decrease earnings per share from $\$ 2,40$ to $\$ 2,28$

Different levels of earnings retention and equity dilution give different impacts on growth but in general it can be expensive to service new equity. What the simplistic approach above ignores is that equity can be far cheaper than debt provided the timing of equity markets is well handled. Secondly the equation used assumes that an increase in the share growth rate has no effect on the earnings growth rate. If they are correlated by virtue of the ability of the company to use the equity injection to acquire technology, scale capacity, distribution channels, or any strategic benefit much of the argument falls away.

\section{The trade-offs}

A judicious combination of return on investment, debt, equity, and earnings retention is called for. Sensitivity analyses can be carried out on the company balance sheet (Zakon, 1971: 14) and the results will obviously vary from balance sheet to balance sheet depending on the ratio of debt to equity, etc. In general the following is valid:

- Increases in margin generate cash in the short term but erode market share and cost advantages associated with the experience curve effect.
- Debt can be used to fund growth. Limits to leveraging occur and very high levels of debt can lead to negative gearing if interest rates move too high too soon.

- Equity is costly to service.

- Earnings retention is the best way of funding growth as it allows for the retained equity to be levered up again with debt to generate an added benefit.

It is obvious that the trade-offs involved in formulating financial strategy must be made explicit owing to the interrelationship between debt, equity, dividends, and margins. The relationships can be made explicit and can be used to calculate the firm's maximum sustainable rate of growth.

\section{The maximum sustainable intemal rate of growth}

The firm has a maximum sustainable rate of growth from internal sources and its ability to lever up equity with debt. The relationship can simply be derived (Zaken, 1971) from the relationships

$$
\begin{aligned}
& \text { Profit }=\text { return on assets } \times \text { total assets }- \text { interest } \times \text { debt } \\
& P \quad=r(D+E)-i D
\end{aligned}
$$

where $r$ is the return on investment, $D$ is the debt, $E$ is the equity, and $i$ is the interest rate.

Collecting terms and dividing both sides of the equation by $E$

$P / E=D / E(r-i)+r$

Dividend payments reduce this rate of growth and the effect of dividend payments can be modelled by multiplying the expression by $p$, the proportion of earnings retained. Noting also that $P / E$ is the sustainable growth rate, $g$.

$g=D / E(r-i) p+r p$

where $g$ is the sustainable growth rate, $D$ is the debt, $E$ is the equity, $r$ is the return on investment, $i$ is the interest rate, and $p$ is the proportion of earnings retained.

This equation can be used to calculate explicitly the maximum sustainable rate of growth under given debt, equity, and dividend policies, which can be funded from internal sources.

\section{Growth and risk}

There are profound interrelationships between industry growth, competitive advantage, pricing policies, and financial strategies (Zakon, 1971). The system is most complex in rapidly growing industries where large amounts of cash are committed to unfamiliar and rapidly changing businesses with long time horizons in the face of agressively shifting competition and demand patterns. The risk elements are exacerbated because:

- Time horizons tend to be long before adequate returns are made (Zakon, 1971, and Biggadike, 1979).

- Capital requirements are high, particularly in capitalintensive industry, whether it be fixed or working capitalintensive businesses.

- The dynamics of growth tend to be subtle and not clear from reported operating data. Product life cycles, although a neat abstraction, tend to be hard to analyse and forecast, and sales patterns are affected by seasonal, cyclic, and random effects. Market information is often difficult and costly to acquire.

- The higher the rate of growth in industry demand, the greater the need for cash. If demand grows at $20 \%$ per annum the industry as a whole must earn $20 \%$ just to generate the funds necessary to add capacity to meet 
demand. Assuming a once annual asset turnover and no debt it implies that profit margins on sales after tax must also be $20 \%$. As pointed out earlier, too high a margin invites competitive entry. This means that it is possible to become locked into a strategic trap because it means that companies with high growth rates

- are cash hungry;

- cannot generate funds for dividends;

- cannot spin off cash into other businesses, either to enhance the earnings of a corporate parent or for investment hedges against obsolescence, or to develop a new business; and

- cannot easily finance growth in excess of the industry average.

- Industries with high profit margins and high growth may report rapidly growing earnings but never realize these earnings for the shareholder in the form of dividends. This occurred to companies in the germanium transistor industry where annual earnings increases of $25 \%-50 \%$ were reinvested for growth but never paid out because of the advent of the silicon transistor.

The risks involved are that firms

- will not reinvest their earnings, or resort to very high margins and erode their future competitive position owing to loss of market share and cost benefits gained from the experience effect, or

- will reinvest earnings in assets that will never pay out.

The net effect of a heavy investment programme must be an asset base that continues to ensure the competitiveness of the firm in future markets and ensures the ability of the firm to generate future profits and dividends. Many semiconductor firms built up substantial levels of retained earnings which were either noncompetitive assets or assets employed in businesses that were becoming obsolete.

Retained earnings are paid out when annual earnings plus depreciation exceed investment needs or when there is a substantial positive cash flow. This occurs under two conditions:

- When the company can both sustain growth and pay dividends owing to a decreased capital (cash flow burden) and a competitive cost position. This means the ability to maintain market share, to sustain high debt levels, and the possession of low cost structures.

- When the firm liquidates its market share by growing more slowly than the industry and by generating more funds than it invests. This can be done by growing more slowly than the industry average, even though still at a rapid rate, or by eroding market share by too high a margin. If an experience curve exists, both low growth and erosion of market share imply the generation of cash at the expense of future production costs relative to the competition.

\section{Capital structure, production costs and competitive position}

The capital structure, production costs and competitive position of a business are functions of the business growth rate and relative market share.

The impact of growth rate on strategy is twofold. First the growth rate of the market is a major factor influencing the ease of entry, and hence the cost, of gaining market share. Attempts to gain market share in low growth markets require an actual reduction in the volumes of competitors' sales. The dominant industry competitors are likely to close ranks to force out unwelcome competitors and, interested in maintaining capacity, may resort to predatory price cutting. In high growth businesses market share can be increased by capturing the largest share of differential growth in the business, by expanding capacity earlier than competitors, by ensuring product availability, and by effective selling support despite the strains imposed by growth (Hedley, 1977: 9-15). Competitors may, in fact, be unaware of the erosion of their market share because their actual volume of throughput has been maintained or increased. Provided capacity is fully utilized, competitors may not be perturbed by loss of share particularly if unaware of the experience effect on costs.

Hedley (1977) cites the British motorcycle industry as an unfortunate example of this. The British allowed their market share throughout the world to erode for more than a decade during which time the British factories remained full. British production volumes in motorcycles held up at around 80000 units per year in the sixties. In sharp contrast Japanese export volumes leapt from only 60000 in 1960 to 2,5 million in 1973 and their total production volumes almost tripled. While Japanese real costs were falling British real costs were not (The Boston Consulting Group, HMSO, 1975). If in addition the Japanese strategy of cornering a market segment, and getting real cost reductions, before moving on to a higher segment using modular design and exploiting the cost advantages is considered, it shows why the British motorcycle industry faced bankruptcy in the early seventies (Robinson, 1982a).

Secondly, growth provides for investment opportunities if it is possible to plough cash into growth in order to obtain a compounded return at a future date. The faster a business grows, the greater the cash drain in the early stages.

Because prices and costs tend to decline with units produced (Robinson, 1982a, and The Boston Consulting Group, 1970) as a function of cumulative experience, and since the producer with the largest stable market share eventually has the lowest costs and therefore the greatest profits, (Figure 2) it becomes vital to have a dominant market share for as many products as possible (Robinson, 1982a and Hedley, 1976: 2-11). On maturity of the industry the industry leader will have the lowest costs and the highest sustainable margins, and will be able to maintain the position as industry leader with the highest shareholder returns (Zakon, 1971: 20) and pay the highest dividends.

In terms of financial strategy the following become critically relevant:

- Once the industry growth rate slows down the industry leader is able to maintain market position with a minimum debt level and maximum dividend payout.

- The marginal firm in the industry has to maintain the highest debt levels and the lowest dividend payouts just to stay alive.

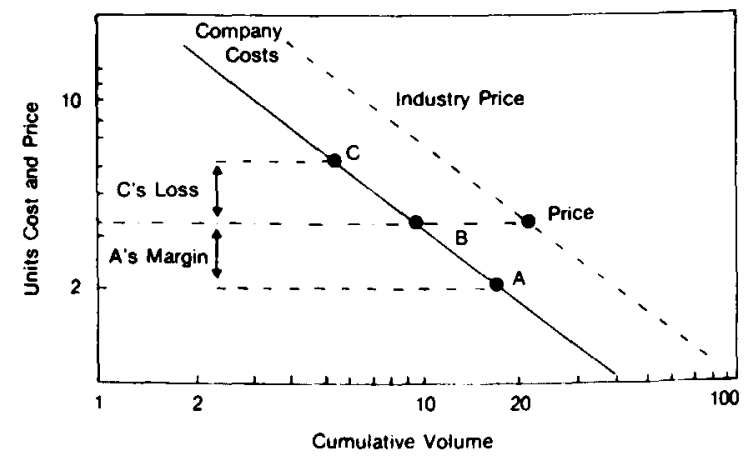

Figure 2 The strategic cost benefit associated with high market share in an experience-driven industry 
The payoff for gaining market share appears to be far out of proportion to either the costs or risks involved, and the financial strategy in terms of the allocation of cash resources to opportunities is a major contributor to achieving market share in growing businesses.

The strategic implications are that a company should strive to dominate a market either by new product introduction or by discouraging competitive entry by pre-emptive pricing. Segmentation of a market by the development of product offerings targeted at a market segment with very specific needs can buffer a company from undifferentiated competition.

Developing or introducing new products, though a good road to dominance, involves considerable costs and uncertainty (The Boston Consulting Group, 1970). Similarly it is also difficult to isolate those segments in which competitors have more experience and lower costs. The key to successful segmentation is to find a segment which can be defended. In contrast, the idea of pre-empting the market by price or value concessions is intuitive to most business organizations. The Boston Consulting Group claims that although price competition is usually resisted, it is often cheaper than the more intangible weapon of added value. (This conclusion jars in view of the Boston Consulting Groups' advocacy of segmentation, which implies product differentiation. Added value, itself, implies both differentiation and a quality edge (Schoeffler, 1979 and Buzzel, 1978). These issues are considered later)

This implies that market dominance must be an explicit objective in the entry phase of a growth product and that pricing is of the utmost importance, mainly downwards, at a time when capital requirements demand substantial earnings. The trade-offs between return, debt, equity, and dividends lead to a number of important conclusions.

- High profit margins do not necessarily indicate an attractive business and reported earnings are not always meaningful. It is usually in the interest of the business to keep margins down to discourage entry into the market.

- Aggressive use of debt and high levels of dividend retention can both sustain reduced prices relative to competition and finance an increase in market share. Entry into high growth industries should only be contemplated by firms willing to accept high levels of debt leverage or by mature companies, with substantial cash flows available and debt capacity, based on a stable business able to pay out high dividends.

The full use of financial resources in a high growth business should allow a firm to achieve the lowest prices in the industry and, even at lower prices, lead to sustainable cost and profit margin advantages owing to the rapid growth in cumulative market share. Industry dominance compounds itself since the resulting stability of margins and sales allows both a greater use of debt and a higher degree of cash spin off to protect future market position. Conversely, the firm which underutilizes financial resources falls behind in costs and finds either, or both, its margins squeezed or market share diminishing. It begins to find its strategic options foreclosed.

As shown in Figure 2, once industry growth slows, the marginal firms live at the mercy of the industry leader. For example the dominant firm, $\mathbf{A}$, in Figure 2 could increase its debt ratio, cut its dividend payout, grow at a high rate and price below that of firm B. Even if A does not use this strategy on $\mathrm{B}, \mathrm{B}$ can use it on $\mathrm{C}$.

Financial strategy can be used to grow and achieve cost advantages. The danger to an industry leader is that a competitor may grow fast enough to become low cost through the correct use of financial strategies unless the leader responds.
The danger to the followers is that the leader may utilize both its cost position and its financial strengths.

The rewards for the low cost producer are

- a dominant competitive operating position,

- dominant competitive financial power, and

- the ability to pay the highest dividends

Cost dominance is a payoff from growth. Industry leaders can sustain growth in one product line while funding another. The industry leader can fund research and development and maintain new product leadership in a dynamic industry by debt or by intra corporate dividends from one business to another. Fledgling growth businesses can be given huge debt equity ratios through the capacity of the parent. The injections of cash can allow them to grow much more rapidly than firms lacking the backing and they can thus attain industry leadership.

In short, companies must generate either cash and debt capacity or growth.

\section{The growth share matrix}

Clearly a product line, division or a subsidiary of a conglomerate must generate either cash flow or growth. The Boston Consulting Group's approach to setting strategy for a portfolio of companies is predicated upon two models, namely

- that of the experience curve, and

- the product life cycle.

The experience curve effect requires that market share be pursued to drive down costs in the long run and that the dominant share company should possess an unassailable cost advantage over competitors. Lower costs imply that the company should have higher margins than competitors and as a result much higher profitability and cash flows. It becomes convenient to use market share as a surrogate variable for experience in an industry, as market share is highly correlated with experience, particularly if share changes have not been abrupt or dramatic. High market share then means high experience and low costs, implying high margins and profitability. High market share means improved cash flows. Low market share points to the unavailability of cash and profits.

The product life cycle likewise impacts into the expected cash flow of a product or industry. Although not discussed in detail, it is implied that brands, products and industries all possess life cycles (Robinson, 1982b) and that the cash flowdetermining factors are associated with the dynamics of the growth cycle rather than whether the object of attention is a brand, product, or an industry. This approach avoids the question as to the existence of differences between product strategies and brand strategies in the application of the growth share matrix in strategy setting. The question does not appear to have been considered by the Boston Consulting Group or other prominent academics and practitioners.

The rate of growth of a product area or an industry is most important and is a major influencing factor on the ease and cost of gaining market share. In low-growth businesses gains in market share tend to require an actual reduction in competitors' sales. Competitors react. In capital-intensive industries where capacity utilization is particularly important the competitors are prepared to fight to prevent the throughput through their plants from dropping, and nasty forms of coalition formation and price competition often result. Conversely, in high-growth industries market share can be gained by securing differential increments in growth ahead of competitors; by expanding capacity earlier than competitors and assuring product availability and effective selling support 
despite the strains imposed by growth. Competitors may be unaware of loss of market share as capacity continues to be fully utilized and may even be unconcerned owing to the high utilization of assets.

High rates of market growth continually require cash to fund increases in both fixed and working capital particularly in capital-intensive industries.

As an integrative planning technique, the Boston Consulting Group's approach is distinguished by the special way in which roles are assigned to each product in a multiproduct company, to each division in a multidivisional company, and to each company in a conglomerate. These different roles are integrated into a strategy for the portfolio of businesses. Product roles are assigned on the basis of the two dimensions of market growth rate and company competitive position.

Market growth rate, as discussed earlier has a profound effect on cash flow and competitive dynamics in a market. Company competitive position is strongly correlated with market share and is heavily influenced by the company cost position $v i s-\grave{a}$ - $v i s$ the competition. In experience-driven industries the simplest measure of company competitive position is the company's relative market share where relative market share is defined as the company's market share divided by that of the largest competitor. The largest competitor in a market has a relative market share greater than one and a competitive cost advantage owing to experience and scale effects. The smaller competitors have lower profitability and generate less cash than the market leader.

Each product market with its competitive situation is unique (Hammond \& Allan, 1975). The differences in growth and cash flow potential and competitive position determine which products represent investment opportunities and which should be used to supply investment funds. Those with neither growth potential nor cash-generation abilities are candidates for elimination from the portfolio. The objective is to get the best overall performance from the portfolio while ensuring that the portfolio is kept in cash flow balance.

Portfolio analysis revolves around the construction of a growth share matrix of the portfolio of products or individual business units. The relative market share and the market growth rate are calculated and plotted on a two by two grid with market growth as the ordinate and relative market share as the abscissa. The ordinate is scaled in the conventional way starting from zero at the foot. In general the mid-point of the grid is at a growth rate of $10 \%$ though industry or other considerations could lead to the choice of a higher rate than $10 \%$. The mid-point of the relative market share grid is at 1,5 and the scale decreases from left to right. In general a $\log$ scale is used because of the fact that the experience effect is concerned with relative cost positions and hence relative profitability (Robinson, 1982: 15). This is because the experience effect implies that profit margin or rate of cash generation differences between competitors should tend to be related to the ratio of their relative competitive positions, or market share (Hedley, 1977: 9-15). The abscissa is usually scaled from 0,1 to 10,0 with 1,5 as the mid-point. The Boston Consulting Group claims that 1,5 is used because in highgrowth businesses relative strengths of 1,5 or greater are required in order to ensure a sufficiently dominant position (Hedley, 1977). In low growth businesses acceptable cash flow generation characteristics are observed at relative strengths as low as 1,0 times. A second line at 1,0 can be used in lowgrowth areas to indicate this (Figure 3).

Products are plotted on the growth share matrix by using a circle with an area proportional to any key variable under

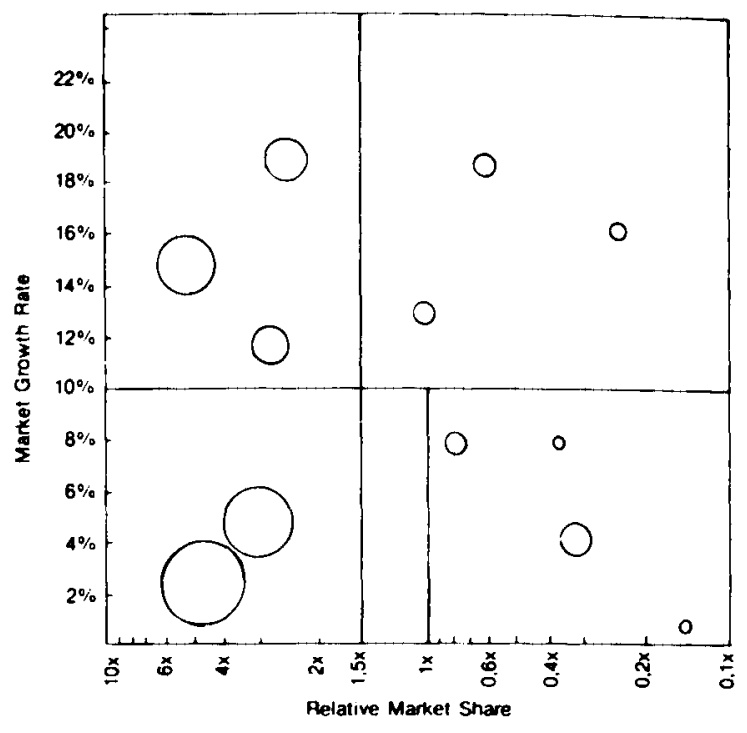

Figure 3 The growth share matrix

consideration, usually sales. Other variables such as capital intensity could be used. The technique facilitates the visual comparison of products with a range of sales volumes, etc. as strategy is usually developed around the existing core businesses or major product areas. In practice proportional diameters are often used instead of proportional areas (Do most strategists sem to find it difficult to take square roots?). This is often optically misleading. A sample of such a portfolio chart is shown in Figure 3.

Similar charts should be developed for each major competitor. A series of charts at various points in time provides a series of visual strategic projectories for each business and indicates both the direction and rate of movement of each product over time.

The use of portfolio charts hinges primarily on the previously considered relationships between market share and profitability and market growth rate and cash flow. Because market share and profitability are positively correlated, market dominance, wherever feasible, is considered the appropriate competitive objective in high growth markets (Hammond \& Allan, 1975). In low growth markets, where it is more difficult and costly to gain share, the strategic objective becomes one of maximizing cash flow, possibly even at the expense of losing market share. The strategy followed for any business depends on the assessment of competitive strength, the cost of gaining market leadership and the funds availabie within the portfolio. The portfolio display helps in understanding the competitive positions of products or businesses, with respect to the strategies of dominance and cash generation. When applied to competitors the portfolio display amplifies the company's own strategic analysis and gives some insight into the competitive dynamics in the market place.

Products are classified on a portfolio chart by market growth rate and by market share. In general, the market growth rate is usually not under the control of the individual company and is influenced by uncontrollable external factors. Portfolio strategy reduces to a market share strategy (Hammond \& Allan, 1975).

The strategic implications of the growth share matrix are bound by four general principles (Hammond \& Allan, 1975):

- The experience curve links high margins and low costs with high market share. Margins and generated cash therefore depend on market share.

- High rates of market growth require high levels of reinvest- 
ment in fixed and working capital if share is to be maintained or increased. Maintenance of market share requires infusions of cash.

- Increases in market share need to be financed and cash must be invested in advertising expenditure, competitive pricing, and additional plant and equipment.

- As the market approaches maturity, growth in the market slows. Cash is generated, particularly if associated with high market share, and this cash must be reinvested in other still growing products.

Those products to the left of the relative market share line of 1,5 are expected to have high profits and good sustainable cash flow. Those to the right are expected to have lower profits and less, or negative, cash flow. Those businesses below the market growth rate cut-off line are expected to require relatively little investment to hold market share while those above the growth rate cut-off point are likely to be cash hungry and to require cash to fund growth.

The growth share matrix differentiates between four distinctly different categories of strategy based on the cash flow characteristics of each of the quadrants of the growth share matrix and each quadrant has acquired a name indicative of its ability to either generate cash flow or dominate the market. The four quadrants of the Boston Consulting Group's strategic menagerie are shown in Figure 4 and are called respectively cash cows, dogs, wildcats, and stars.

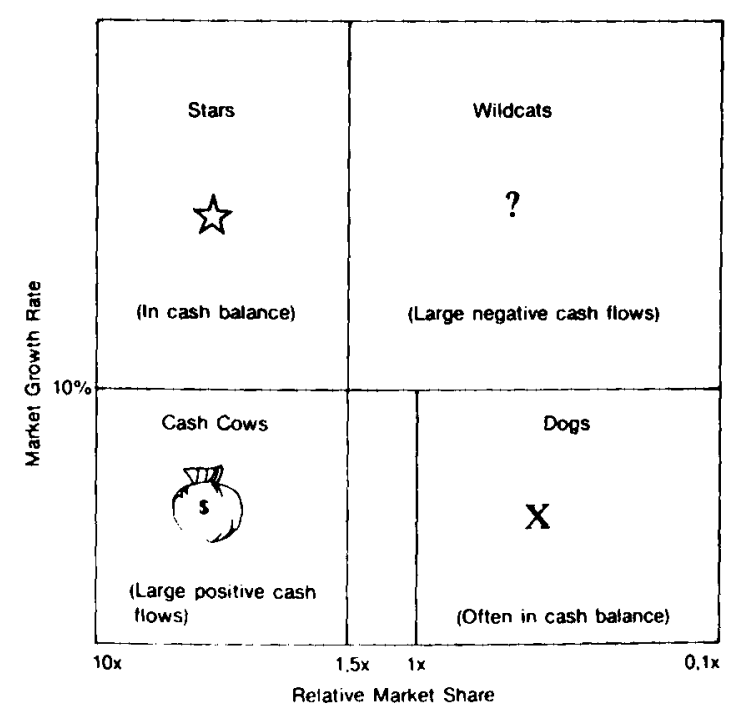

Figure 4 Strategic classifications on the growth share matrix

\section{Cash cows}

Low market growth, dominant market share businesses have an entrenched market position, low costs, and little funding requirements. Profits and cash generation are good and large cash surpluses should be generated by these businesses. Cash cows pay the dividends and interest, provide the debt capacity, pay the corporate overhead, and provide the cash for investment elsewhere in the company's portfolio of businesses (Hedley, 1977). Cash cows are not attractive areas for investment and their good earnings should not be used incorrectly to justify continued investment in the hope that growth can be increased. The objectives should be to maximize cash flow consistent with retaining market dominance, including investments in the retention of technological leadership. Pricing decisions should be made with an eye to maintaining price leadership. Pressure to over invest in product proliferation and market expansion should be resisted unless exceptionally attractive prospects exist for expanding primary demand. Excess cash should be deployed elsewhere.

\section{Stars}

High growth, dominant market share businesses are growing fast and have substantial reported profits associated with the need for lots of cash to fund growth (Day, 1977: 29-38). Star businesses are frequently roughly in balance on net cash flow and can be self-sustaining in growth requirements. They represent the best growth and investment opportunities available to the company and every effort should be made to maintain and consolidate their competitive position (Hedley, 1977). Stars may sometimes require heavy investment beyond their own generation capabilities and low margins may be necessary to deter competition. This is worthwhile in the longer term for as market growth slows large cash returns should be generated owing to market dominance. The business drops into the cash cow category with a competitive edge in terms of cost per unit owing to the experience effect. Heavy, but inadequate funding however can be dangerous if the business is unable to establish market dominance and becomes number three or so on the experience curve with a sharply deteriorated cost position. The stars then become dogs, which tend to be losers.

\section{Wildcats}

High-growth, low-share businesses have the worst cash characteristics of all. This is reflected in the names sometimes used for the upper right hand quadrant of the matrix; names such as wildcats, question marks and problem children. The combination of rapid growth and poor profit margins creates an enormous demand for cash. If the market position is not improved before market growth slows, the business will become frozen in and become a dog. Three clear-cut strategy options exist:

- Firstly, heavy commitment of financial and management resources must be made to gain market share and to fund the business to dominance so that it can become a star, and ultimately a cash cow, when the market matures. Heavy investments must be made to get a disproportionate share of new sales or to buy existing market share by acquiring competitors. This strategy can prove to be very costly in the short term and require substantial resources. It is the only sound way of developing a question mark over the long term (Hedley, 1977). Since the resources in a portfolio are limited, the number of businesses which can be aggressively supported must be limited.

- Secondly, if resources are not available to move a business out of this quadrant it should be divested. Outright sale is preferable but is often not possible. Under these circumstances a decision should be made not to invest further in the business and that the business must simply be allowed to generate whatever cash it can without reinvestment. The business should decline rapidly if growth is high. Short-term cash will be generated at the expense of market share but this seems preferable to the error of perpetually sinking cash into the business without improving its prospects.

- Thirdly, consideration should be given to strategic market segmentation if a defensible niche can be identified and the resources are available to gain dominance (Day, 1977: $29-38$ ). This strategy is even more attractive if the segment chosen can provide an entreé, a source of funds, and an experience base from which to push for market dominance. 


\section{Dogs}

Low-growth, low-share businesses have a poor competitive position which condemns them to poor profits. Because market growth is low there is little potential for gaining sufficient market share in order to obtain a viable cost position. Market share gains are likely to be strenuously resisted by the dominant share producer. The cash required in the business just to maintain competitive position, although low, frequently exceeds that generated especially under conditions of high inflation (Hedley, 1977). The business becomes a cash trap which is likely to absorb cash perpetually unless further investment is vigorously resisted. 'The colloquial term dog describing these businesses though undoubtedly perjorative, is thus rather apt' (Hedley, 1977). Low-growth, low-share businesses also tend to consume vast amounts of management attention. Companies should try to minimize the number of investments which remain in this category.

The strategic options possible include:

- Focussing on a specialized segment of the market that can be dominated and protected from competitive inroads.

- Harvesting profits by cutting back costs to some minimum supportive level which will maximize cash flow over the forseeable life time.

- Liquidation in as clever and as graceful a manner as possible usually involving the sale as a going concern.

- Abandonment of the business and deletion of the product line.

- Strategic pricing to upset competitors. Price cutting to precipitate a price cut by the market leader with an impact on the market leader's cash flow.

\section{Overall strategies}

In reality businesses cover a smooth spectrum across the matrix. There is no sudden alchemy which transmutes a star into a cash cow as its growth declines from $11 \%$ to $9 \%$. Changes occur gradually and the transition points are merely guidelines to assist in strategic thinking. The location of products on the portfolio chart is indicative of the current strategic position and cash flow status of the portfolio (Abell \& Hammond, 1979). The ongoing success of the portfolio depends on the existence of businesses that generate cash and provide acceptable profits and businesses that use the cash generated to fund future market dominance and cash generation. Setting strategy involves analysing the current status of the portfolio and forecasting the expected trajectories of individual businesses, followed by the creative allocation of cash among existing opportunities. The aim is to create a strong, successful, ongoing portfolio.

Vertical movements in the matrix, that increase the market growth rate, are usually beyond the power of the individual company. However, sometimes company policy can influence primary demand as occurred when Black and Decker expanded in the hand-held electric tool market by reducing prices as costs fell with experience. The reduced prices not only helped share but increased primary demand by putting more products in reach of the consumer (Abell \& Hammond, 1979 and Cvar, 1980). Similar examples must exist in other industries ranging from semiconductors through hand-held calculators to motorcycles. Although not documented, it cannot simply be assumed that in some businesses the market leader, for example Texas Instruments in calculators or Honda in motorcycles, cannot influence primary demand, particularly in a market protected by entry barriers such as tariffs, etc.

For most companies however, it is assumed that the market growth rate is beyond company control and must be forecast.
If no changes in market share occur businesses will fall vertically as market growth slows and their position on market maturity will be a function of their market share in the high growth phases. Wildcats will become dogs unless sufficient investment is made during high market growth phases to transform them into stars. Stars will become the future cash cows and ensure cash generation capability in the matrix.

The following cash flow and investment criteria, as graphically portrayed in Figure 5, result:

- The first goal should be to maintain the position of cash cows and to guard against the temptation to invest in them excessively (Hedley, 1977).

- Second priority should be to use the cash generated by the cash cows to maintain and consolidate the position of those stars which are not self-funding to prevent them from gradually becoming wildcats.

- The remaining cash should be used to fund a selected number of wildcats to market dominance. The cash should be used to fund those wildcats which have some semblance of a strong competitive position or the possibility of attaining one. Most companies will have inadequate cashgeneration capacity to fund all of their wildcats to dominance. Those with weak competitive positions will be liabilities and should either remain in the portfolio on a selffunding basis, which will ultimately doom them to becoming dogs, or they should be divested.

- Finally most companies have a number of dogs in the portfolio. 'There is nothing reprehensible about this; indeed on the contrary, an absence of dogs probably indicates that the company has not been sufficiently adventurous in the past' (Hedley, 1977). It is essential, however, that the fundamentally weak position of the dog be recognized for what it is. Occassionally it may be possible to restore a dog to viability by creative business segmentation, rationalization and specialization for a small target market segment, or niche, which the business can dominate. It is usually impossible to rescue the dog by attempting to go for market dominance as this is unreasonably costly in mature businesses. Dogs should be managed for cash and investments should not be made in the business. Management should be particularly wary of expensive turnaround plans advocated for a dog if the plan does not involve a very fundamental change in the dog's competitive position. 'Without

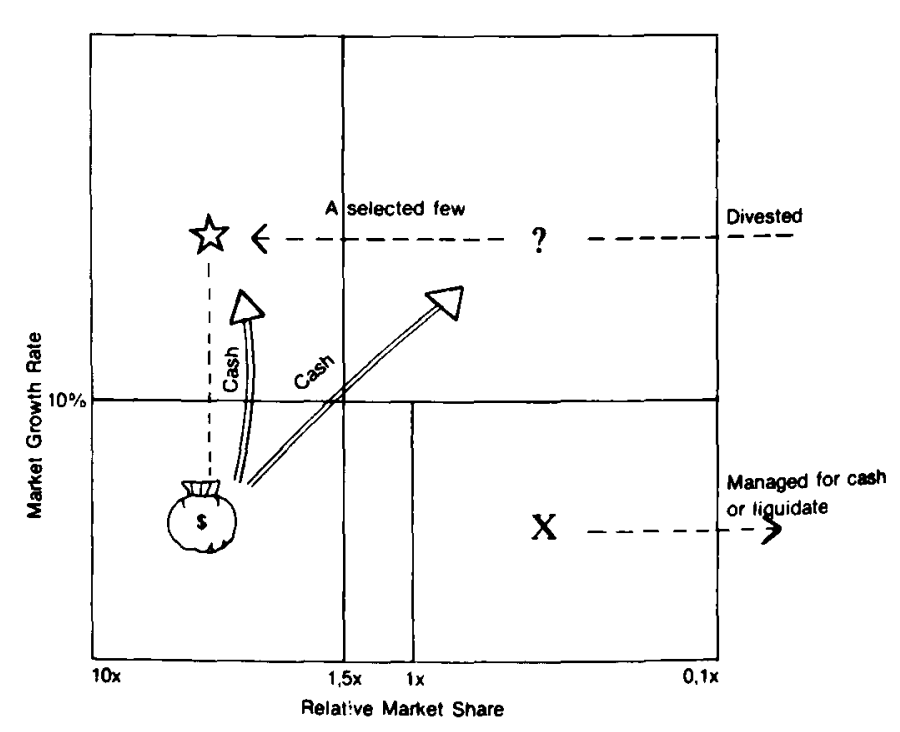

Figure 5 Strategic progress, cash flow and investment criteria on the growth share matrix 
this the dog is a sure loser. An indictment of many corporate managements is not that their companies have dogs in the portfolio, but rather that the dogs are not managed according to logical strategies' (Hedley, 1977: 12). The decision to liquidate a business can be harder to take than the decision to enter a business especially if expensive plant and equipment must be written down. Capital intensity, far from being just a barrier to entry, is an even more effective barrier to exit. It is essential for the long-term viability of the company that management has the guts to take unpalatable decisions.

Financial strategy based on the portfolio approach is a powerful competitive tool. It does not mean a simplistic conclusion on the use of debt and the retention of dividends. It means the construction of a portfolio of businesses to maximize debt capacity and overall cash generation ability and to redirect cash flows into areas of opportunity. The net result is a continual postponement of corporate maturity and the combination of growing earnings, maximum profit margins in growth areas and maximum financially sustainable growth.

\section{Success and disaster sequences in the portiolio}

Figure 6 illustrates success and disaster sequences in the dynamics of the portfolio chart. The wildcat is adequately funded to become a large star which, on market maturity, transmutes into a large cash cow. Substantial investment in a mediumsized star was inadequate to maintain market share so that the business eroded position to become a large wildcat which in turn, on market maturity, is transformed into a large dog. Inadequate attention to the maintenance of competitive position for a medium-sized cash cow results in a medium-sized dog.

A well-balanced portfolio is shown in Figure 7. The firm shown is a UK company analysed in the course of a Boston Consulting Group assignment (Hedley, 1977). There is a firm foundation consisting of three substantial cash cows and a few well-placed stars to provide growth and high returns and cash flow on market maturity. A few wildcats exist which are sufficiently well-placed to be funded into stars at a reasonable cost not out of proportion to the company's resources. Some dogs exist which, if well-managed, should not be a drain on cash.

Figure 8 shows a seriously out-of-balance portfolio with an inadequate base of cash cows and a high proportion of

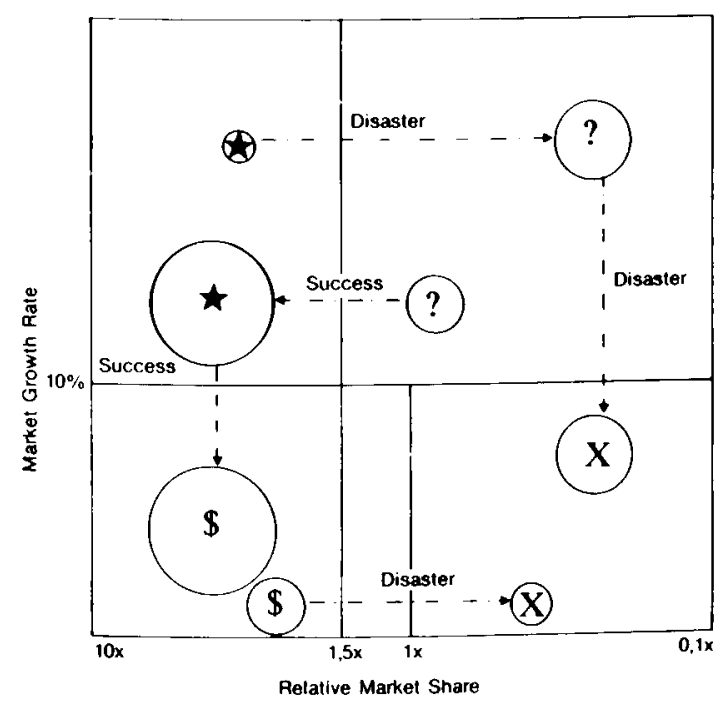

Figure 6 Success and disaster sequences in the dynamics of the growth share matrix (adapted from Hammond \& Allan, 1975: 6.)

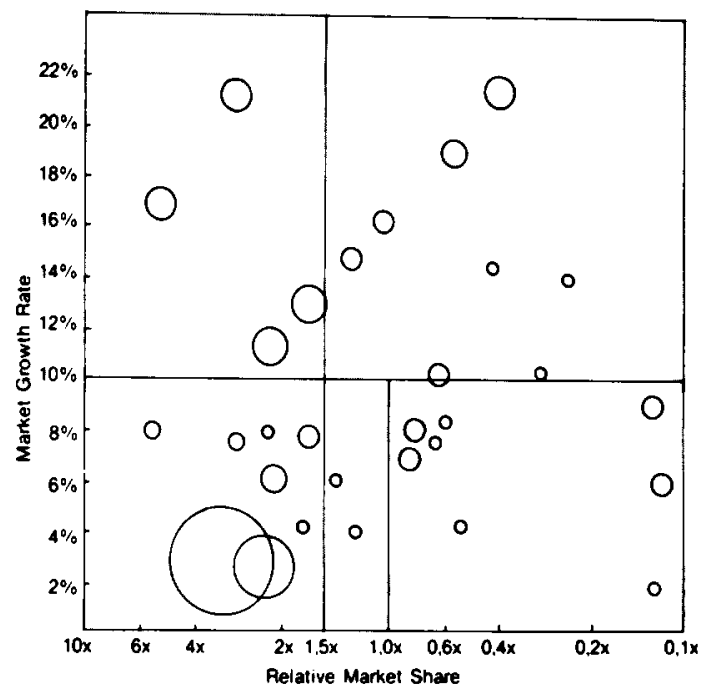

Figure 7 A well balanced portfolio (adapted from Hedley 1977: 12)

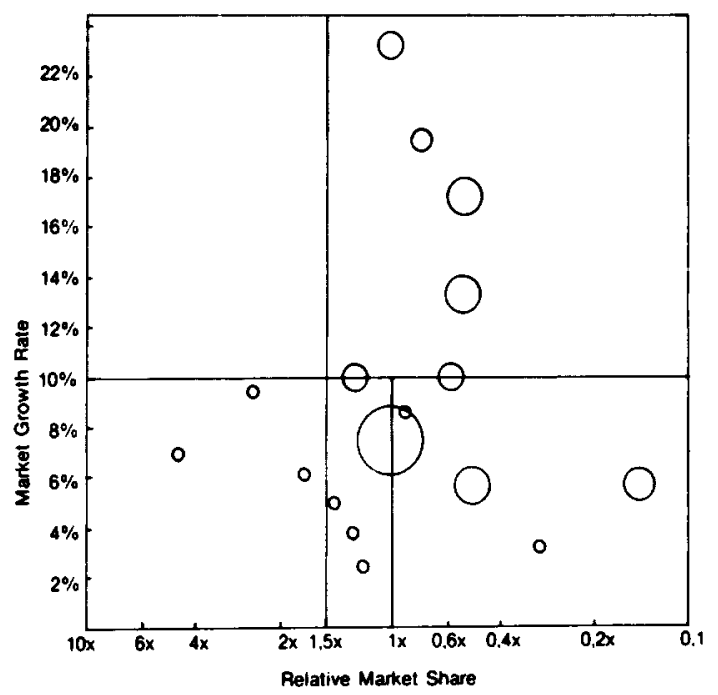

Figure 8 An unbalanced portfolio

question marks. According to the Boston Consulting Group the company concerned was taking such cash as was being generated by its mature businesses and spreading it out among all of its high-growth businesses of which only one was actually receiving sufficient investment to maintain share (Hedley, 1977: 13). The overall competitive ability of the portfolio was declining and the balance of the portfolio was shifting toward the projected portfolio in Figure 9. The overall weight of the wildcats in the portfolio was increasing because of their higher relative growth, making them even more difficult to fund from the limited resources of the mature businesses. Spreading all the available funds between all businesses only increased the rate of decline.

The company was caught in a vicious spiral of decline. To break out of the spiral one or two of the wildcats would have to be selected for funding and the cash taps closed on the reminder. This would require a careful analysis of the businesses concerned and the characteristics of the competitors and their expected competitive reaction. The use of the portfolio matrix highlights the strategic issues involved.

The strategy developed for each business in the portfolio should tend to be uniquely adapted to the matrix position of the business and the capabilities and needs of the overall portfolio. In practice it is common to find all businesses within 


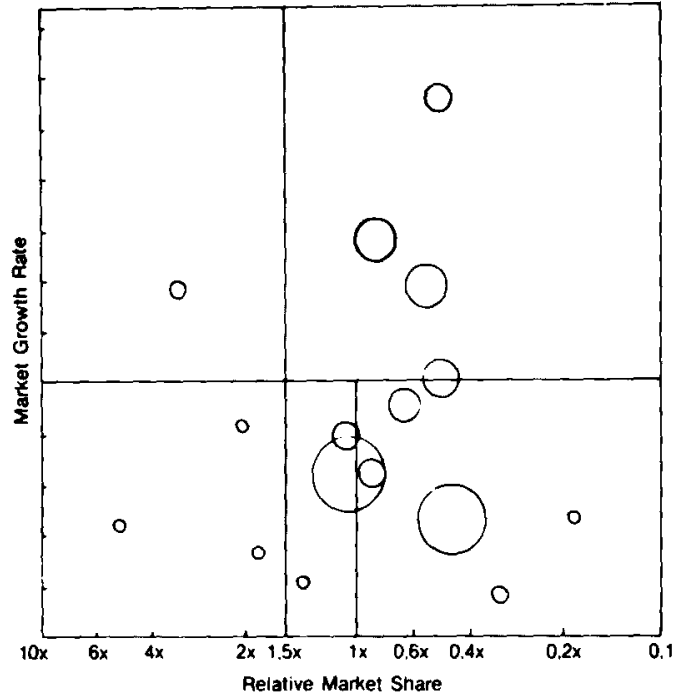

Figure 9 An unbalanced portfolio with liquidity problems

a portfolio being operated with common strategic criteria such as a $25 \%$ pre-tax return on investment and a growth rate of $10 \%$ per annum. These strategic criteria become targets for every business in the portfolio. Cash cows make the return criteria easily enough, though they may fall short on growth. The wizkid manager is praised and is allowed to plough back an excess of cash into the mature businesses. Dogs rarely make the profit target and it is not realized that it is unreasonable for them to make the profit target. The most common mistake is to make major investments in dogs to try and turn them around. Question marks receive funds, possibly even enough to maintain share and turn into large cash traps - the black holes of corporate finance from which cash, like light, is never able to reach escape velocity.

\section{References}

Abell, F. \& Hammond, J.S., 1979. Strategic market planning. Englewood Cliffs: Prentice Hall.

Biggadike, R. 1979. Entry strategy and performance. Harvard University. Doctoral dissertation.

Buzzel, R.D., 1978. Product Quality. The Pimsletter no 4. Massachusetts. Strategic Planning Institute, Cambridge.

Carter, E.E. \& Kalman, J.C., 1972. Portfolio aspects of strategic planning. J. Bus. Policy, vol. 2 (4), 8-30

Cvar, M., 1980. Strategic planning: What is it? Cambridge,
Massachusetts. Strategic Planning Institute.

Day, G.S., 1977. Diagnosing the product portfolio. J. Mark. vol. 41, 29-38.

Hammond, J.S. \& Allan, G.B., 1975. A note on the Boston Consulting Group concept of competitive analysis and corporate strategy. Boston, Massachusetts. Harvard Business School, note 9-175-175.

Hedley, B., December 1976. A fundamental approach to strategy development. Long Range Plann., 2-11.

Hedley, B., February 1977. Strategy and the business portfolio. Long Range Plann., vol. 10, 9-15.

Henderson, B., 1970. Intuitive strategy. Boston. Perspectives no 96. The Boston Consulting Group.

Levitt, T., November - December 1975. Exploit the product life cycle. Harv. Bus. Rev.

Levy, H. and Sarnat, M., 1972. Investment and portfolio analysis. New York: Wiley.

Masson, C.R., 1974. Dynamic competitive strategy and product life cycles. Illinois: St Charles Challenge books.

Modigliani, F., Miller, M.H., June 1958. The cost of capital, corporation finance and theory of investment. Am. Econ. Rev., 48, $261-297$.

Moose, S.A. \& Zakon, A.J., 1972. Frontier curve analysis: As a resource allocation guide. J. Bus. Policy. Spring 1972, $63-70$.

Roberts, K., 1981. The profit assessment report. Cambridge. The Strategic Planning Institute.

Robinson, C.G., 1982a. Experience curves as a planning tool. University of South Africa. Working paper, School of Business Leadership.

Robinson, C.G., 1982b. Product Life Cycle Strategies. Pretoria. Working paper, School of Business Leadership, University of South Africa.

Schoeffler, S., 1979. Recession: Who gets hurt? How to cope? Massachusetts. The Pimsletter, no 14. The Strategic Planning Institute. Cambridge.

Schoeffler, S., Buzzel, R.D. and Heany, D.F., March, April 1974. Impact of strategic planning on profit performance. Harv. Bus. Rev., $137-145$.

Sharpe, W.F., 1970. Portfolio theory and capital markets. New York. McGraw Hill.

The Boston Consulting Group, 1970. Experience curves as a planning tool. Boston. The Boston Consulting Group Inc.

The Boston Consulting Group, HMSO (1975). Strategy alternatives for the British motorcycle industry. A report prepared for the secretary of state for industry.

Zakon, A.J., 1971. Growth and financial strategies: $A$ special commentary. Boston. The Boston Consulting Group, Inc. 